\title{
Native Languages and The Role of Research in Formulating Language Policy
}

Keith Lickers

Ontario has a Native language policy for its schools and this paper will demonstrate how the framework for theoretically-based decision-making in educational language planning as enunciated by Cummins in his position paper applies to the development of that policy.

This paper is concerned with the aboriginal languages of Ontario. In conformity with current practice, the term "Native" is used to refer to aboriginal people, specifically those people who inhabited North American in about 1500 , that is, before the period of significant European migration to this continent, and their descendants. Thus the term "Native languages" refers to their ancestral languages.

Schools for Canadian Native peoples have been administered by a variety of agencies since their institution in the early 1800 s. Most of these schools have operated through the medium of English. In fact, Native children were in the past subjected to emotional and physical punitive practices, which would not be permitted in today's schools, in attempts to prevent them from speaking their Native language.

Since the late 1960s Native language and culture programs have begun to be instituted in schools for status Indian children. The loose administrative structure for providing such programs has been beneficial in some ways, given that different communities have different needs and wishes for these programs. However, the lack of administrative direction has meant that such programs often were offered intermittently, were of uneven quality, and were largely unsupported by supervision, or by the development of curriculum materials and standardization of teacher qualifications.

In 1972, the single most influential document on Native education was published by the National Indian Brotherhood, a national Native organization no longer in operation. That document, Indian Control of Indian Education, calling for direct responsibility for and control of Indian education by Indian people, was accepted in 1973 by the federal Department of Indian and Northern Affairs. It gives details on how its general objectives of reinforcing children's Native identity and providing the training necessary for making a good living in modern society should be carried out. It also made recommendations about administration of education. 
Education for Native children is administered by three bodies: the federal government, the provincial government and Indian bands as a result of Indian Control of Indian Education. Today, 49 percent of status Indian children in Ontario attend provincial schools, 46 percent attend federal schools, and 5 percent attend band-controlled schools. Given those statistics, the Ontario Ministry of Education felt it had a responsibility to meet the linguistic and educational needs of Native students in Ontario.

It is against that background that this paper will demonstrate how the development of Ontario's Native language policy followed the sequential stages outlined by Cummins.

\section{Examine Perceived Problems}

The document Indian Control of Indian Education (1972) pointed out that the Native languages were being lost and that the younger generations could no longer speak or understand their mother tongue, that is Indian identity was to be preserved, steps had to be taken to reverse this trend. Native people advocating initiatives in Native education, including Native language programs, looked to the schools to accomplish their aims.

Are Native languages in danger of disappearing? It seems that, while there are ten surviving Native language in Ontario, only two are not considered at risk of being lost. Foster (1982: 7-16) shows the situation concerning languages spoken in Ontario:

\begin{tabular}{lrrr}
$\begin{array}{l}\text { Ontario } \\
\text { Languages }\end{array}$ & \multicolumn{1}{c}{$\begin{array}{c}\text { In } \\
\text { Canada }\end{array}$} & $\begin{array}{l}\text { Outside } \\
\text { Canada }\end{array}$ & $\begin{array}{c}\text { Total } \\
\text { Speakers }\end{array}$ \\
\hline Cree & & & \\
Delaware & 55,000 & - & $55,000-60,000$ \\
Ojibwe & $5-10$ & less than 100 & less than 100 \\
Potawatomi & $30,000^{*}$ & $10,000-20,000$ & $40,000-50,000$ \\
Cayuga & $100^{*}$ & 1,000 & 1,100 \\
Mohawk & 360 & $10^{*}$ & 370 \\
Oneida & $2,000^{*}$ & $1,000^{*}$ & 3,000 \\
Onondaga & $200^{*}$ & $50^{*}$ & 250 \\
Seneca & $50-100$ & $100-150$ & 250 \\
Tuscarora & 25 & 400 & 425 \\
& 7 & 40 & 47
\end{tabular}

Note: * indicates that the number of speakers in this category is not known.

Foster points out that only minority languages with more than 5,000 speakers are not considered in danger of extinction. Of Canada's Native 
languages that still have any speakers, only Cree, Ojibwe and Inuktitut are in the favoured category.

In the 1981 census, 15 percent of Ontario's Native groups reported a Native language as their mother tongue. Ten years earlier it was 42 percent. In 1971, 33 percent of those declared ethnically Indian said that an Indian language was most often spoken in their home. In 1981 it was 12 percent.

In comparing the 1981 figures to those for 1971, it can be seen that the rate at which Native mother tongue speakers tend to use English in the home is rising. However, in terms of loss of Native language use, these figures are particularly important given the relatively small population of speakers. From a North American perspective, the special implications regarding the loss of Native languages in North America as opposed to the local loss of languages of immigrants from elsewhere in the world is that there is no other repository of living speakers for these languages. Given all of the above, the last opportunity to help Native people retain and regain their languages for future generations will occur during the next five to ten years.

\section{Generate Hypotheses About Causes in Light of Theory and Research}

The federal government, with responsibility for the education of Indian children on reserves, undertook to make education for status Indian children until the early 1970 s as much like that of other children as possible. In provincial schools, English is the medium of instruction. Thus, the federal government stipulated that English was to be the medium of instruction for its schools. This, no doubt, contributed to loss of Native language use on a continent where even a language like French with large numbers of speakers and an active national campaign of support, still has difficulty holding its own (Mougeon and Canale 1978/79).

An analysis of 1971 census figures shows that the shift to English from the Native languages does not happen evenly across the province (Burnaby 1980). In terms of Native language use, Native communities in southern Ontario showed only 12.5 percent to 17.7 percent of the population with a Native language as their mother tongue. This could be explained in that these communities have been in close contact with non-Native society for several centuries. In mid-northern Ontario, the trend to English was not as advanced. About half the Native population spoke a Native language as their mother tongue. Compared with the southern Ontario Native communities, the Native language situation in these mid-northern communities seemed somewhat more stable.

In northern Ontario, 79.2 percent of Native people reported that a 
Native language was their mother tongue. In 1971, English had yet to gain a real foothold in the north. A similar analysis of the 1981 census figures has not been done. However, given the great increase of electronic media broadcasting into northern areas and the expansion of air and ground transportation networks in the past decade, it seems likely that language switch to English is also taking place in the north.

\title{
3. Plan Solutions to Problems: Identify Goals and Means
}

Native people advocating initiatives regarding Native languages look to schools to accomplish their aims:

\begin{abstract}
While much can be done by parents in the home and by the community on the reserve to foster facility in understanding, there is a great need for formal language instruction in the language. (National Indian Brotherhood 1972: 14-15).
\end{abstract}

In presentations to the Ontario government by various Native organizations, it was repeatedly pointed out that efforts must be made to reverse the trend towards Native language loss by restoring full fluency in the respective ancestral languages of Native people and that those efforts should be taken on by the schools.

In the early 1980s the Ministry of Education took its first real steps towards meeting the challenge of the objectives for Native languages put forward by the Native people. It was necessary to begin consultations with Education officials of the federal Department of Indian and Northern Affairs for two reasons: first, the federal department had been conducting Native language programs in its schools in Ontario for about fifteen years and it had to be determined why the Native people were still expressing concern about Native language loss; and second, the federal department had been involved since 1972 with the training and certification of Native language instructors.

In the first instance, it was learned that no curriculum development had taken place, making it difficult for Native language instructors to put together well-planned programs for their classes. The largest focus for Native language programs were Grades 1, 2 and 3. It was rare to find classes in Native languages in the Junior Division (Grades 4, 5 and 6) and even rarer to see Grade 7 and 8 classes where a Native language was taught.

In consultations with Native language instructors it became apparent that there was a need for a clear set of objectives and a need for curricular materials as well as teaching resources. The instructors also expressed concern that they had no real status in the education community since they were not perceived as educators by other teachers in the school. Their certification, after successfully completing an instructors certification pro- 
gram, was a diploma, not a teaching certificate.

To resolve the situation, a number of activities needed to be undertaken:

- $\quad$ prepare new curriculum guidelines for Algonquian languages and Iroquoian languages;

- provide a certification program to enable successful candidates to obtain teaching certificates;

- provide support services to Native language teachers;

- provide consultative services to school boards offering Native language programs;

- provide grants to school boards to offer Native language programs in schools;

- provide financial assistance to facilitate the development of language support materials.

\section{Implement Interventions to Resolve Problems}

In June 1984 the Ontario Cabinet approved a Native Language Policy for Ontario schools. The Policy stated that:

- the teaching of a Native language would be incorporated into the regular school day in elementary schools;

- Native language courses would be offered for credit in secondary schools;

- implementation of the Native language program would begin in Ontario schools in September, 1986.

Soon after the endorsement by Cabinet, the Ministry of Education embarked on two major fronts to implement the policy - development of a curriculum guideline for Native languages and the development of a syllabus for a Native Language Teachers' Certification Program. The curriculum guideline is comprised of three parts and Part A: Policy and Program Considerations was distributed to schools in May, 1987. Part B: Language Patterns for Algonquian Languages and Part C: Language Patterns for Iroquoian Languages should be available in November, 1987.

The Native Language Teachers' Certification Program was first offered in the summer of 1986. It is a three-part program leading to a Permanent Letter of Standing that permits the holder to teach the language of specialization, either Algonquian or Iroquoian, in any elementary or secondary school in Ontario. Two Faculties of Education are involved Lakehead University for Algonquian languages, and The University of Western Ontario for Iroquoian languages.

Relevant regulations have been revised to legitimize the function of Native languages as subjects in the curriculum of schools and Native language teachers have been given status as certificated teachers coming 
from an accredited certification program. Funding to school boards is in place when a board establishes a Native-as-a-Second-Language Program in its schools. The board will be eligible for a grant to off-set the Native language teacher's salary, development of learning materials, development of texts and so on, based on the enrolment in the program.

\section{Monitor (or Initiate) Research Relevant to Theory About Causes or Problem}

Three Native language consultants have been seconded for three years to the Ministry of Education to provide support services to Native language teachers as well as providing consultative services to school boards offering Native language programs. These people will keep abreast of research and experiments elsewhere which are relevant to the policy.

\section{Evaluate Success or Failure of Intervention}

Since Ontario's Native language policy is a new initiative, a number of indicators will be used to gauge its success, such as:

- an increase in the number of Native communities wanting a Native language program offered;

- an increase in the number of school boards offering a Native language program;

- an increase in the number of students enrolled in a Native language program;

- an increase in the number of people enrolled in the Native Language Teachers' Certification Program;

- a demand for additional teacher/learning materials;

- whether Indian and Northern Affairs, Canada implements a similar language policy for its schools.

Also, it is anticipated that Native students who have an opportunity to study Native languages as a recognized part of the school program will demonstrate better attendance, a more positive sense of self-identity and higher rate of completion of education and skills-training programs. These results could lead to higher achievement, better employability, leadership in the community and greater participation in the wider society.

\section{Communicate Intervention Results to Policy-Makers, Education and Public}

Ontario's Native language policy will be evaluated in 4-5 years. Indicators of success or failure of the intervention should have become manifest by that time. 


\section{CONCLUSION}

In the preceding discussion, this paper has described how the relationships between research, theory and policy apply in the context of Ontario's Native language policy. It has also demonstrated support for the statement by Cummins "that research and theory ... are applied to policy ... where there is a relatively high degree of consensus in regard to both the societal and educational goals of the initiatives." It has also pointed out that the formulation of Ontario's Native language policy was justified on moral grounds.

\section{REFERENCES}

Burnaby, B. (1980). Language and their roles in educating Native children. Informal series 16. Toronto: OISE Press.

Foster, M. K. (1982, Winter/Spring). Canada's indigenous languages: Present and future. Language and Society, 7, 7-16.

Mougeon, R., \& Canale, M. (1978-79). Maintenance of French in Ontario: Is education in French enough? Interchange, 9:4, 30-39.

National Indian Brotherhood. (1972). Indian control of Indian education. Ottawa: National Indian Brotherhood.

\section{THE AUTHOR}

Keith Lickers is a Seneca Indian from the Six Nations Reserve. He taught elementary school there and served as Executive Director of the Woodland Indian Cultural Education Centre before joining the Ministry of Education of Ontario in 1974. Since that time he was instrumental in developing the "People of Native Ancestry" series of curricular publications. He developed the Native language policy for Ontario which was implemented in 1987. He produced the Native Languages guidelines and was involved in the establishment of the Native Language Teachers' Certification program which began in the summer of 1986. 